\title{
21 COVID-19 and federalism in Spain
}

\author{
Mario Kölling
}

\subsection{Introduction}

In 2018, Spain was ranked as healthiest in the world by the Bloomberg Healthiest Country Index. The Index also ranked its highly decentralized health system as third in terms of efficiency. However, the country's aging population and the accompanying increase in the incidence of chronic diseases are potential risks to the system's sustainability. Funding cuts to healthcare following the 2008 financial crisis have led to increasing variability in the quality of healthcare services in Spain. This variability can be seen across the 17 Autonomous Communities (ACs) and 2 autonomous cities the constituent units in Spain - which assume the responsibility for the delivery of these services.

Taken together with earlier funding constraints, the COVID-19 pandemic remains an unprecedented challenge. COVID-19 is severely testing both the Spanish federal territorial model and the National Health System (NHS). During 2020, Spain was one of the worst-hit countries in the world both in terms of infections and deaths (Table 21.1). The first nationwide "state of alarm" based on Article 116 of the Spanish Constitution (SC) lasted from 14 March to 21 June 2020. During this state of alarm, in which the central government took over the decision-making in the NHS, Spain entered a "new normalcy" in late June, during which social distancing measures remained in place. Since late June, the ACs governments gradually re-assumed powers to deal with the pandemic and took the main decisions in health care. However, in September 2020, a second wave outbreak once again pushed Spain to the bottom of the European Union's rankings, although the impact throughout the country was very different. Following requests from most of the ACs - including Catalonia and the Basque Country - the central government adopted a second "state of alarm" at the national level on 25 October.

Several Spanish scientists explained the high number of infections and deaths in Spain as due to the low capacity for PCR tests, scarcity of personal protective equipment, and critical care equipment but also due to delayed reactions by central and ACs governments, and the poor coordination among central and ACs authorities were all contributing factors (Garcia-Basteiro et al. 2020). In fact, I argue in this paper that the COVID-19 crisis has above all revealed the structural weaknesses of the Spanish territorial model. In particular, it has become clear that vertical and horizontal intergovernmental coordination instruments and joint decision-making bodies were insufficient to respond to the crisis appropriately. Nevertheless, during the crisis, the coordination and common decision-making among the levels of government improved and later reached unprecedented levels across the board.

DOI: 10.4324/9781003251217-21 
Table 21.1 Key Statistics on COVID-19 in Spain as of 10 January 2021

\begin{tabular}{lllll}
\hline $\begin{array}{l}\text { Cumulative } \\
\text { Cases }\end{array}$ & $\begin{array}{l}\text { Cumulative Cases per } \\
100,000 \text { Population }\end{array}$ & $\begin{array}{l}\text { Cumulative } \\
\text { Deaths }\end{array}$ & $\begin{array}{l}\text { Cumulative Deaths per } \\
100,000 \text { Population }\end{array}$ & $\begin{array}{l}\text { Case-Fatality } \\
\text { Percentage }\end{array}$ \\
\hline $2,025,560$ & $4,332.3$ & 51,690 & 110.6 & 2.6 \\
\hline
\end{tabular}

Source: World Health Organization Weekly epidemiological update - 12 January 2021. Geneva: WHO, 2021. Available from https://www.who.int/publications/m/item/weekly-epidemiological-update

\subsection{COVID-19 in Spain}

Spain has been hit hard by COVID-19, with more than 1,000,000 cases and more than 50,000 confirmed deaths, as of the end of December 2020 (Ministerio de Sanidad 2020). More than 50,000 health workers had been infected, and nearly 25,000 deaths were in nursing homes. With a population of 47 million, these data place Spain among the worst-affected countries.

The situation from March to June 2020 and from July to December 2020 created two very different maps across Spain, with varied effects between ACs. At the top of the list was the AC Madrid, with 13,236 cases per 100,000 inhabitants. It was followed by the AC Navarre with 12,594 cases for every 100,000. There are several reasons for the asymmetry and for the different map.

Most of the Spain's COVID-19 cases occurred in large urban areas during the first wave for these reasons:

- High population density;

- High mobility;

- A tendency toward physical proximity and greetings; and

- More than 20 percent of the population over the age of 65 .

At the beginning of the second wave, the role of seasonal workers in the agriculture sector and their poor living conditions led to higher numbers of cases in rural areas. But the numbers soon increased in the urban centers as well reaching new maximum levels at the beginning of November.

The confinement measures taken in response since mid-March 2020 have resulted in an unprecedented contraction of economic activity in the first half of the year, with the service sector - especially tourism - being the most affected. The economic indicators improved in May, when restrictions started to be lifted in a gradual and differentiated way across sectors and ACs. However, changes in consumer behavior, reduced flight connectivity, disruptions in global value chains, and weak demand impeded a normalization of economic activities during 2020 and for the foreseeable future. According to the European Commission autumn forecast, the annual GDP growth in 2020 is forecast at almost -12.5 percent. Activity may continue recovering during the second half of 2021 and then moderate gradually in 2022. This would bring annual GDP growth to about 5.1 percent in 2021 (European Commission 2020). The public budget balance (\% of GDP) will rise to 12.2 and the Gross public debt (\% of GDP) to 120.3 at the end of 2020 . The impact of the crisis on labor-intensive sectors will result in a significant rise in the unemployment rate, while the pandemic is having a disproportionate impact on the poorest and most vulnerable. 


\section{Mario Kölling}

\subsection{COVID-19 and federalism in Spain}

Since the 1980s, Spain has developed from a unitary state with a longstanding centralist tradition to a strongly decentralized state. The territorial division is based on three levels of territorial organization: 19 ACs (Comunidades Autonomas) among them 2 Autonomous Cities, 50 provinces (Provincias); and 8,124 municipalities (Municipios). According to the constitution, the ACs can adopt their own statutes which define their institutions and powers (Article 148 SC). The statutes must be approved by the regional assembly and the national Parliament. In the constitutional division of powers, some competences are expressly attributed to the central state (Article 149), whereas the AC competences can extend to all matters not allocated to the central state. The exclusive powers of the Spanish state include, among other, the regulation of the basic conditions guaranteeing the equality of all Spaniards. Articles 148, 149, and 150 SC specify the competences which the ACs may assume. These include competences related to social assistance, health, among other matters. Today, the ACs have assumed most competences they possibly could (Tudela and Kölling 2020).

The NHS is highly decentralized and based on the principles of universality, free access, and equity. Although the NHS is financed from general tax revenue, the ACs assume the responsibility for the delivery of healthcare services. The central government retains the responsibility for certain strategic areas as well as for the overall coordination and national monitoring of the health system. Since 2001, the ACs have developed strong administrative capacity to implement national regulations and develop region-specific policies. Coordination on health matters between the central government and ACs is routed through the Interterritorial Council for the NHS (OECD 2019).

The General Public Health Law of 30/2011 establishes the model for the management of any epidemiological or pandemic crisis. In 2013, the National Early Warning and Rapid Response System (SIAPR) was created, which assumes the functions of coordination, notification, and evaluation of epidemiological or pandemic crisis. The system received a positive assessment by the Global Health Security Index 2019. The assessment approved both the healthcare capacity of the NHS and the warning capacity of SIAPR. Nevertheless, the model was criticized for its ability to prevent and react to pandemic challenges. The Interterritorial Council merely takes care of coordinating technical measures between health officials among the ACs and the central government within the SIAPR. However, the Council cannot guarantee the coordination of political measures among the central government and the ACs (Arteaga 2020). Several research projects have produced similar results for other policy areas in the past. While the coordination works at the level of technicians, this coordination does not exist at the political level (Arbos et al. 2009). In normal times, the meetings of the Council are held at technical level, and everything goes well. However, during the COVID-19 crisis, it was mainly the health ministers of the ACs and the Spanish health minister who attended the meetings.

Compared to other countries, Spain was a laggard in raising the level of response to the surge of reported cases. The first restrictive measures became effective on $9 \mathrm{March}$ 2020 , when the number of confirmed cases already exceeded 1,500. This contrasts with the responsiveness of other countries, most of which adopted measures when they reached 1,000 confirmed cases. Prime Minister Sánchez declared a nationwide state of alarm on 13 March, following a videoconference with Presidents of all ACs 
when the number confirmed cases already exceeded 7,500 (Timoner 2020). The state of alarm is based on Article 116 SC and on the Organic Law 4/1981. The Royal Decree 463/2020, which came in force on 14 March ), conferred full responsibility to the Spanish government to implement measures to deal with the COVID-19 crisis. The Royal Decree contained measures related to the limitation of the free movement of persons or vehicles, the suspension of procedural and administrative time periods, and necessary action to ensure the supply of property and services needed for health, food, power, and other essential services. The declaration of the state of alarm allowed the central government to suspend the powers devolved to the ACs for a period of 15 days. The Prime Minister delegated authority to the Ministers for Defence, Internal Affairs, Transport, Mobility, and Urban Matters as well as to the Minister for Health in their respective areas of responsibility, with any residual responsibility being assumed by the Minister for Health. With the creation of the mando unico (single command), the Minister for Health formally assumed the responsibility for decision-making and coordination of health policy decisions in the 17 ACs. Although the declaration suspended the ACs powers, it did not suspend the State of Autonomies or reduce the power of the ACs, the central government assumed their power for a very detailed period of time and in response to a very specific situation.

The first state of alarm has been extended six times by parliament at the request of the government and ended on 21 June 2020. The measures undertaken were supported by all ACs at the political and technical level. Nevertheless, considering that decision-making and management have been in the hands of the ACs for almost two decades, the central government's coordination competence has been shown to be very weak. It was very difficult for the Ministry of Health to obtain and provide even basic operational data as well as to coordinate joint actions with the ACs, such as organization of joint trade in the procurement of protective clothing and masks and data management. Besides the mando único, the first reactions consisted of 17 different reactions by the ACs. Because of shortages of equipment and medical supplies, ACs started to compete for these scarce resources and to purchase this material by their own at the international markets.

Some ACs demanded stronger measures to tackle the crisis, like Murcia, or decided to start with COVID-19 tests on their own, like Andalucía. Moreover, the decision of the central government to limit activities which were not considered essential has disproportionately hit industrialized regions such as the Basque Country or tourist regions in Valencia. Although party politics were not very noticeable during the first weeks of the first state of alarm, the Basque nationalist party (PNV) had been very critical about the lockdown measures. It did, however, continue to support the central government in maintaining its majority in the Spanish Parliament. Partisan considerations increased during April and triggered the criticism, especially by the Madrid, ruled by the Partido Popular (PP), a conservative party. The criticism was also based on existing conflicts, as in Catalonia, where the government refused to sign a joint declaration with the central government and the rest of the ACs on coordinating the lockdown. The government there was also reluctant to accept the presence of armed forces for the construction of field hospitals in its territory. However, there was also criticism from the socialist presidents of some ACs due to a lack of information about decision-making processes. The criticism from the head of government in Valencia, the leader of the Partido Socialista Obrero Español (PSOE) in May was particularly clear: "Loyalty does not mean submission!" 


\section{Mario Kölling}

On 28 April, the central government presented a four-phase plan for a gradual transition to a "new normality." With each phase, the social and economic situation has been further normalized. The transition of the provinces (the administrative unit below the ACs) from one phase to the next one was decided by the central government. In this way, the restrictions in the social sector were gradually and asymmetrically lifted without the participation of ACs. Although the method of asymmetric transition to a "new normality" was criticized by the ACs, they came to an arrangement with the central government, which was also increasingly flexible. With the transition to a "new normality," the ACs took over again the competences in the health sector and other areas affected by the state of alert.

After several coronavirus outbreaks in July, ACs started to adapt their own measures, for example, to make the wearing of face masks mandatory in public spaces. Following a legal wrangle due to unclear responsibilities, courts greenlighted most of the restrictions. However, ACs did not get clear legal coverage to adapt several full measures, such as selective confinements or restrictions on mobility. Since coronavirus infections continued to rise, similar strategies were progressively adopted by all ACs. But mainly Partido-Popular-governed ACs - such as Madrid - also demanded that the central government should again take over the control. The Spanish government announced new legal mechanisms in May that would allow to implement measures in "co-governance" with the ACs without having to impose another state of alarm. However, no legislative proposals were submitted by the government to Parliament for nearly four months. Then, at the end of September, the central government and the majority of ACs governments reached an agreement. They would impose restrictions in areas with more than 100,000 residents only if they reached three benchmarks: 500 cases of COVID-19 per 100,000 inhabitants, 35 percent COVID-19 patient occupancy in intensive care units, and positive test results of 10 percent or greater. Nevertheless, the ACs demanded a new nationwide state of alarm in order to impose more severe social restrictions. The second state of alarm was declared by the central government on 25 October and extended until 9 May 2021. This new state of alarm was implemented in a decentralized manner, primarily managed by the Autonomous Community governments.

\subsubsection{Management of fiscal impact and response}

On 17 March, the central government announced a package of $€ 200$ billion to fight the economic fallout of the coronavirus crisis, made up of public and private funds. On July 15 , the parliament approved a $€ 16$ billion aid package to help ACs cover the health, social, and educational expenses of the pandemic. A total of $€ 9$ billion of this was provided as transfers for healthcare, plus $€ 2$ billion to cover the needs of the education system, and $€ 5$ billion to compensate ACs for the decline in their tax revenues. The criteria to distribute these funds among the ACs included population weighted by age, population density and insularity, the number of admissions to intensive care units, total hospitalizations, and total numbers of PCR tests for COVID-19 performed. For education funds, the main criteria included the size of the population under 16 years of age. Finally, the compensation for the decrease in economic activity was allocated according to local taxation revenues, population size, and mobility requirements.

However, this was clearly not enough. A report published at the beginning of 2020 already had warned of the "fragility" of the ACs finances in the face of a possible 
slowdown of the economy (de la Fuente 2020). The COVID-19 crisis was more than a slowdown, and the ACs were facing it with the financing system that was adopted in 2009 and which had been waiting for a reform for years. On 8 May, a new EU regulation allowed ACs to use up to $€ 3.2$ billion of the European Regional Development Fund to cover healthcare extraordinary expenditures such as spending for healthcare equipment, tests, personal protective equipment, and additional workforce or surveillance apps development. In general terms, the relief packages have been smaller in Spain than in other advanced economies, and direct aid has been low. The crisis arrived in Spain when the government had a very small spending margin both in terms of debt and deficit. These restrictions prevented the government from adopting more aggressive measures. For this reason, the government placed all its faith in the European recovery funds.

\subsubsection{Intergovernmental relations}

One of the mayor weaknesses of the Spanish "State of Autonomies" is intergovernmental relations (IGR). The Constitution did not establish an institutional framework that would guarantee continuous political dialog and IGR. Thus, there is neither a permanent institutionalized representation of regional interests at the national level nor a framework for intergovernmental relations. IGR are mainly developed informally or at the bilateral level between the ACs and the central government and are strongly influenced by party politics and parliamentary arithmetic. However, the institutional framework for cooperation and coordination has expanded over the past 30 years and has been extensively used during the COVID-19 crisis. Today, sectoral conferences form the most commonly used IGR mechanism. The legal nature of the conferences is that of a consultative and deliberative body that does not have executive powers; therefore, its resolutions are merely recommendations. Whether sectoral conferences will be convened and which topics will be discussed both depend on the central government. Although sectoral conferences have a political composition, their functioning has shown that they are bodies in which the more technical dimension predominates. While in 2019, 49 sectoral conferences had been held (the average of previous years was 60), in 2020, 166 conferences were celebrated.

The sectoral conference on public health (Interterritorial Council for the NHS Consejo Interterritorial del Sistema Nacional de Salud) has in the past been quite effective and less affected by partisan divisions and considerations when dealing with crises. In early January 2020, the Ministry of Health activated the COVID-19 protocol in coordination with the Departments of Health in the ACs. On February 4 , the conference adopted an emergency protocol reinforcing the coordination and surveillance mechanisms among the central and AC health authorities. During the state of alarm, the conference met online twice a week for information interchange at the highest political level. Even Catalonia, which had not attended these meetings since 2018, participated in the search for common agreements. Since the beginning of the new normality at the end of June 2020, the conference continued to meet very frequently reaching agreements, for example, regarding common standards for PCR tests, closure of bars, the benchmarks to impose social restrictions, and measures in seniors residences. In total, 82 sectoral conferences on public health were held in 2020 - as opposed to 5 in 2019. All ACs implemented most of these agreements, within which they developed their own legislation. Central and ACs authorities also 


\section{Mario Kölling}

reached asymmetrical agreements involving different sectorial conferences, such as health and agriculture, or at the bilateral level.

The Conference of Presidents is also an example of the increasing dynamic of intergovernmental cooperation and also of the lack of constitutionally guaranteed joint decision-making. This conference has been held since 2004 on a de facto basis and represents the highest political level for multilateral cooperation between the Prime Minister and the presidents of the 17 ACs and the Autonomous Cities of Ceuta and Melilla. The Conference was convened only seven times between 2004 and 2020 but met in weekly online meetings during the first state of alarm. All presidents participated in these meetings. At the end of the state of alarm, after 14 meetings, most of the presidents of the ACs stressed the usefulness of the Conference during the management of the COVID-19 crisis. In fact, according to Carolina Darias, Minister for Territorial Policy of the Spanish government, the plan to move from the state of alarm to the "new normality" in late June was elaborated in close collaboration with the ACs. Once the ACs assumed again their competences during the new normality, the meetings have been convoked with less intensity. However, during the three conferences held between June and October, several common agreements were reached, including one on the redistribution of the EU recovery fund. In this sense, the vertical IGR improved on a quantitative and qualitative level, but the horizontal IGR continue to show traditional patterns of IGR in Spain and therefore do not exist.

\subsection{Transformations in COVID-19 and federalism in Spain}

The COVID-19 crisis has above all revealed the structural weaknesses and cyclical problems of the Spanish territorial model. From the central government to the municipalities, vertical intergovernmental coordination instruments and joint decisionmaking bodies were insufficient to respond to the crisis appropriately. From Catalonia to the Canary Islands, horizontal intergovernmental coordination is non-existent. During the pandemic, the tension between the constitutionally determined framework legislation of the central government and the reality of heterogeneous regional health systems was also revealed.

Furthermore, decisions were taken very late and slowly due to the institutional weakness, the unclear division of competences and lack of legal endorsements as well as party politics and territorial cleavages. This assessment is not new. "The limits and vitiated dynamics of the Spanish decentralization that, long before we knew about this virus, was already an ill-equipped territorial model to cope with any serious challenge in a federal way" (Grau, Sanjaume-Calvet 2020). Many initiatives to reform the system, especially after the economic and financial crisis, have not been successful. These failures were due to many reasons, including party politics and the conflict in Catalonia which hindered reforms of the territorial model for a decade.

The pandemic has not served to build "trust and loyalty" (Munarriz 2020), but there are also positive lessons that could be learned. During the past months, there has been an unprecedented level of interaction and common decision-making between the different levels of government. This activity may be the ground for an institutionalization of the Conference of Presidents, including rules of procedure for joint decision-making and a permanent secretariat.

A further strong point was the flexibility of the model. During the first state of alarm, the central government imposed comprehensive restrictions throughout Spain, 
with severe impact on the economy and social life. Then, since the end of June, the ACs took decisions by their own depending on the health situation in their territory. Finally, the second state of alarm was adopted with fewer restrictions, allowing ACs to specify measures within a certain common range. This policy divergence reduced the limitations to specific hot spots and contributed to learning effects among ACs. The most important effect was the move toward coordinated actions, such as the framework agreement for centralized purchase for healthcare products signed at the beginning of August by all ACs - with the exception of Valencia - and the central government (Ministerio de Sanidad 2021). The expected savings with this aggregate purchase will exceed $€ 300$ million.

Another positive effect was the role of the Spanish government within the EU. Since the beginning of the pandemic, the government demanded a strong European mechanism to face the consequences of the crisis and presented several initiatives. Accordingly, the EU Council decision issued in July commits the EU to support Spain during the coming years in economic terms but may also connect this support with certain conditions such as reforms of the labor market and the pension system. Spain will receive close to $€ 140$ billion over the next six years from a $€ 750$ billion coronavirus recovery fund. Resources will be mobilized to support recovery and to reorient the economy toward a more inclusive and sustainable kind of growth. Spain also will receive $€ 21.3$ billion from the EU SURE program to assist the country in addressing the increases in public expenditure to preserve employment.

Drawing from the experience of the crisis management so far, the Health ministry and the ACs have already drafted their reflections on the challenges that the NHS must address. This document, now an Action Plan, includes initiatives aimed at strengthening the NHS to prepare it to tackle and even anticipate future challenges. The Plan will also strengthen the essential capacities which the NHS needs in times of normality. Moreover, some specific proposals have already been announced to improve the co-governance between the central government and ACs.

\section{Bibliography}

Arbós, M.X., Colino, C.C., García, M.M.J. and Parrado, D.S., 2009. Las relaciones intergubernamentales en el Estado autonómico. La posición de los actores. Barcelona: Institut d'Estudis Autonómics. Barcelona: Generalitat de Catalunya. Available from: http://www. gencat.cat/drep/iea/pdfs/IEA_64.pdf [Accessed 3 February 2021].

Arteaga, F., 2020. La gestión de pandemias como el COVID-19 en España: ¿enfoque de salud o de seguridad? Madrid: Real Instituto Elcano, ARI 42/2020-13/4/2020. Available from: http://www.realinstitutoelcano.org/wps/portal/rielcano_es/contenido?WCM_GLOBAL_ CONTEXT=/elcano/elcano_es/zonas_es/ari42-2020-arteaga-gestion-de-pandemias-covid19-en-espana-enfoque-de-salud-o-de-seguridad [Accessed 2 February 2021].

de la Fuente, Á. 2020. Una mini-reforma de urgencia de la financiación autonómica para una mejor respuesta a la crisis, Fedea Policy Papers - 2020/05 Available from: https://www. fedea.net/una-mini-reforma-de-urgencia-de-la-financiacion-autonomica-para-una-mejorrespuesta-a-la-crisis/ [Accessed 11 March 2021].

Garcia-Basteiro, A., Alvarez-Dardet, C., Arenas, A., Bengoa, R., Borrell, C., Del Val, M. Franco, M., Gea-Sánchez, M., Gestal Otero, J., González López Valcárcel, B., Hernández, I., Carles March, J., Martin-Moreno, J., Menéndez, C., Minué, S., Muntaner, C., Porta, M., Prieto-Alhambra, D., Vives-Cases, C. and Legido-Quigley, H. 2020. The Need for an 


\section{Mario Kölling}

Independent Evaluation of the COVID-19 Response in Spain. The Lancet, 396 (10250), 529-530. doi: 10.1016/S0140-6736(20)31713-X [Accessed 11 March 2021].

Grau-Creus, M., Sanjaume-Calvet, M. «Loyalty does not mean submission!»: On the Covid19 measures and the apparently surprising features of the Spanish territorial model. UACES Territorial Politics Available from: https://uacesterrpol.wordpress.com/2020/05/26/loyaltydoes-not-mean-submission-on-the-covid19-measures-and-the-apparently-surprisingfeatures-of-the-spanish-territorial-model/ [Accessed 11 March 2021].

Ministerio de Sanidad, 8 April 2020. Actualización no 177: Enfermedad por el coronavirus (COVID-19). Available from: https://www.mscbs.gob.es/en/profesionales/salud Publica/ccayes/alertasActual/nCov-China/documentos/Actualizacion_177_COVID-19.pdf [Accessed 11 March 2021].

Ministerio de Sanidad, 2021. Notas de Prensa: El Ministerio de Sanisterio de Sanidad licita un acuerdo marco para adquirir material sanitario y equipos de protección individual para el SNS por un valor de mas de 2.500 millones de euros [The Framework Agreement for Buying Personal Protective Equipment by the Central Government for the ACs]. Available from: https://www.mscbs.gob.es/gabinete/notasPrensa.do?id=5023 [Accessed 11 March 2021].

Munarriz, A., 2020. El "test de estrés" del virus destapa los fallos y lagunas del Estado autonómico [online]. infoLibre, 6 July. Available from: https://www.infolibre. es/noticias/politica/2020/06/29/1a_pandemia_pone_prueba_estado_autonomico_ test_estres_muestra_fatiga_materiales_107485_1012.html [Accessed 11 March 2021].

OECD and European Observatory on Health Systems and Policies. 2019. Spain: Country Health Profile 2019, State of Health in the EU. Paris: OECD Publishing.

Tudela, J. and Kölling, M. 2020. The Kingdom of Spain. In: Griffiths, A., Chattopadhyay, R., Light, J. and Stieren, C. eds. Handbook of Federal Countries. London: Palgrave - Forum of Federations.

Timoner, A. 2020. Policy Responsiveness to Coronavirus: An Autopsy. Agenda Pública - El País, 8 June. 